\title{
EFEKTIVITAS KEPEMIMPINAN KARISMATIK KYAI DALAM MENINGKATKAN KINERJA GURU
}

\section{THE EFFECTIVENESS OF KYAI KHARISMATIC LEADERSHIP IN IMPROVING TEACHER PERFORMANCE}

\author{
A Ajan'1a, A Mahrudin'1 ${ }^{1}$ dan MA Mulyana ${ }^{1}$ \\ 1 Program Studi Manajemen Pendidikan Islam, Fakultas Keguruan dan Ilmu Pendidikan, \\ Universitas Djuanda Bogor, Jl. Tol Ciawi No. 1 Kotak Pos 35 Ciawi Bogor 16720 \\ a Korespondensi: A Ajan, Email: zhanblancos@gmail.com \\ (Diterima: 05-03-2018; Ditelaah: 05-03-2018; Disetujui: 23-04-2018)
}

\begin{abstract}
This study aims to find and analyze data about the effectiveness of kharismatic leadership of the Cleric in improving teacher performance in integrated islamic boarding school Darussyifa Al-Fithroh YASPIDA Sukabumi. This research is a kind of quantitative research. The results of this study suggest that the cleric charismatic leadership in in integrated islamic boarding school Darussyifa Al-Fithroh is "effective" charismatic leadership. The effectiveness is obtained from Kai Square calculations obtained by price $x^{2} 0119,3925$. This result can then be compared with the criticism price (significance level) $x^{2}$ t $5 \%$ with dk $8=$ 15,507 . Thus it can be concluded that $\mathrm{x} 2 \mathrm{o}$ (observation) is greater than $\mathrm{x}^{2 \mathrm{t}}$ (table) at $5 \%$ significance level. This research is recommended to cleric and teacher in boarding school as reference material in improving the effectiveness of cleric's charismatic leadership in improving teacher performance In integrated islamic boarding school Darussyifa Al-Fithroh YASPIDA School of Sukabumi.
\end{abstract}

Keyword: charismatic leadership, teacher performance, the efefectiveness.

\begin{abstract}
ABSTRAK
Penelitian ini bertujuan untuk mengetahui dan menganalisis data tentang efektivitas kepemimpinan kharismatik kyai dalam meningkatkan kinerja guru di Pondok Pesantren Terpadu Darussyifa Al-Fithroh Perguruan YASPIDA Sukabumi. Penelitian ini merupakan jenis penelitian kuantitatif. Hasil penelitian ini menyatakan bahwa kepemimpinan kharismatik kyai di Pondok Pesantren Terpadu Darussyifa Al-Fithroh adalah : kepemimpinan kharismatik "efektif". Keefektifan tersebut diperoleh dari perhitungan kai kuadrat yang diperoleh harga $x^{2}$ o 119, 3925. Hasil ini kemudian dapat dibandingkan dengan harga kritik (taraf signifikansi) $\mathrm{x}^{2} \mathrm{t} 5 \%$ dengan $\mathrm{dk} 8=15,507$. Dengan demikian dapat disimpulkan bahwa $\mathrm{x}^{2} \mathrm{o}$ (observasi) lebih besar dibandingkan $\mathrm{x}^{2} \mathrm{t}$ (tabel) pada taraf signifikansi 5\%. Penelitian ini direkomendasika kepada Kyai dan Guru di Pondok Pesantren sebagai bahan referensi dalam meningkatkan efektivitas kepemimpinan kharismatik Kyai dalam meningkatkan kinerja guru Di Pondok Pesantren Terpadu Darussyifa Al-Fithroh Perguruan YASPIDA Sukabumi.
\end{abstract}

Kata kunci: efektivitas, kepemimpinan kharismatik, kinerja guru.

Ajan, A., Mahrudin, A., \& Mulyana, M. A. (2018). Efektivitas Kepemimpinan Karismatik Kyai dalam Meningkatkan Kinerja Guru. Tadbir Muwahhid, 2(1), 33-45. 


\section{PENDAHULUAN}

Pondok pesantren merupakan sebuah lembaga pendidikan yang di pimpin oleh seorang kyai. Berkembang atau tidaknya pondok pesantren tergantung sepenuhnya pada kepemimpinan kyainya. Beberapa pondok pesantren mengalami kemunduran karena kyainya meninggal dunia dan tidak ada penerus yang cocok untuk memimpin lembaga yang dipimpinnya. Kelangsungan hidup sebuah pesantren sangat bergantung pada kemampuannya untuk mempersiapkan generasi kiai penerus yang berkapabilitas tinggi apabila suatu ketika ditinggalkan seniornya.

Keberadaan seorang kyai pondok pesantren berdasarkan peran dan fungsinya dapat dipandang sebagai pemimpin multi fungsi, disamping perannya sebagai pemimpin pondok pesantren, kyai juga bertugas menyusun kurikulum, membuat tata tertib, merancang sistem evaluasi sekaligus melaksanakan sisem belajar mengajar berkaitan dengan ilmu yang dia juga sebagai pembina pendidik umat, serta pimpina masyarakat.

Di antara kepemimpinan kyai, terdapat beberapa gaya kepemimpinan kyai, salah satunya adalah gaya kharismatik kyai. Kepemimpinan kharismatik kyai mampu mempengaruhi dan mengatur pengikutnya dengan jumlah yang sangat besar. Gaya kepemimpinan yang kharismatik ini memang dalam kepentingan tetentu, sangat dibutuhkan karena masih membawa manfaat.

Dalam menjalankan pondok pesantren, kyai tidak berjalan sendiri, melainkan perlu ada orang-orang yang dapat membantu dan mendukung dalam pelaksanaan kegiatan di pondok pesantren. Guru termasuk salah satu faktor yang paling mendukung kyai dalam proses pembelajaran. Sehingga tujuan yang diinginkan kyai akan terwujud dengan adanya dukungan dari para guru. Tujuan tersebut tidak dapat tercapai manakala guru-guru tidak menjalankan apa yang telah menjadi tugas dan tanggung jawabnya dengan baik.

Kinerja guru ialah kemampuan seorang guru dalam pelaksanan pembelajaran dan bertanggung jawab atas murid dibawah bimbingannya dengan meningkatkan prestasi belajar murid. Kinerja guru juga dapat ditunjukkan dari seberapa besar kompetensi-kompetensi yang dipersyaratkan dipenuhi kompetensi tersebut meliputi kompetensi padagogik, kepribadian, sosial dan professional. Kinerja tersebut akan timbul tergantung kepemimpinan kyainya. Apakah dapat menimbulkan motivasi sehingga guru memiliki kinerja yang baik, ataupun sebaliknya guru semakin jauh dari kinerja yang diharapkan.

Pondok pesantren terpadu Darussyifa AlFithroh sebagai objek kajian penelitian, karena dengan berstatus sebagai lembaga pendidikan nonformal yang memiliki keunikan tersendiri dalam bidang pelaksanaan kepemimpinan kyai dengan berbagai tipe kepemimpinan yang beragam. Kepemimpinan yang diterapakn ini didampingi dengan manajemen yang baik pula. Gaya kepemimpinan kyai di pesantren ini mengacu pada kepemimpinan kharismatik.

Kepemimpinan kharismatik kyai perlu ditinjau dan di evaluasi bagaimana pelaksanaanya terkait guru-guru yang di pimpinnya dan dinilai tingkat keberhasilannya. Dalam menghasilkan kinerja guru yang baik, tidak hanya dalam pendidikan formal tetapi pendidikan nonformal. Salah satu pesantren dari komponen kepemimpinan kharismatik kyai yaitu tujuan, isi, cara dan penilian. Evaluasi 
kepemimpinan kyai yaitu bagaimana mengukur keefektifan penerapan tipe kepemimpinan kyai yang ada di Pondok Pesantren Terpadu Darussyifa Al-Fithroh terhadap proses peningkatkan kinerja guru.

Berdasarkan latar belakang tersebut penulis fokus melakukan penelitian berjudul "Efektivitas Kepemimpinana Kharismatik Kyai dalam Meningkatkan kinerja guru di Pondok Pesantren Terpadu Darussyifa Al-Fithroh". Penelitian ini berwujud demi mengetahui tingakat kefektifan kepemimpinan kharismatik kyai terkait meningkatkan atau tidaknya kinerja guru.

\section{MATERI DAN METODE}

\section{Jenis Penelitian}

Penelitian yang digunakan adalah metode penelitian deskriptif yaitu dengan cara melaui pendekatan kauntitatif. Metode deskriptif ialah metode dengan cara melakukan penelitian dalam status sekelompok manusia kemudian, objek, set, kondisi, sistem pemikiran ataupun dalam suatu kelas sering terjadi peristiwaperistiwa yang kurang baik pada zaman sekarang. Tujuan dari Penelitian ini ialah untuk membuat suatu deskripsi atau gambaran beberapa fakta, sifat-sifat dan hubungan antara fenoma terjadi dan sedang diselidiki.

Dalam penelitiannya para peneliti menggunakan dengan metode deskripsi ini karena rumusan masalah yang sering terjadi, berkenaan dengan pertanyaan terhadap variabel mandiri, baik hanya satu variabel atau lebih dari satu variabel (variabel yang berdiri sendiri).

Dalam penelitian ini, peneliti tidak membuat beberapa perbandingan variabel itu dengan sampel lain, dan mencari adanya hubungan variabel itu dengan variabel yang lainnya (Sugiyono 2006).

Dalam pelaksanaan metode penelitian yang kuantitatif yaitu penelitian yang memiliki landasan filsafat positivesme yang digunakan untuk meneliti populasi dan sampel tertentu, pengumpulan untuk beberapa data yaitu menggunakan instrumen dalam penelitian, dan nalisis data yaitu bersifat kuantitatif atau statisitik, dengan memiliki tujuan untuk menguji dan menyimpulkan yang sudah ditetapkan.

\section{Waktu dan Tempat Penelitian}

Waktu penelitian dimulai pada awal bulan maret 2017 sampai juni 2017 semenjak melantaskan pengamatan awal penyalinan proposal berbatas pelaporan laporan penelitian. Tempat penelitian yaitu di Pondok Pesantren Terpadu Daussyifa AlFithroh Perguruan Yaspida Sukabumi.

\section{Target Penelitian}

Pengkajian ini dijalankan beserta mengambil subjek kyai dan guru di Pondok Pesantren Terpadu Darussyifa Al-Fithroh yang di dalamnya bukan terdapat Pondok Pasantren dan sekolah yang terdiri dari, SD IT YASPIDA, SMP IT YASPIDA, MTs YASPIDA, SMA PLUS YASPIDA, MA TAKHOSUS YASPIDA, SMK TERPADU 1 YASPIDA, SMK TERPADU 2 YASPIDA dan SMK AGROBISNIS YASPIDA. Kegiatan yang diamati adalah efektifitas kepemimpinan kharismatik kyai dalam meningkatkan kinerja guru.

\section{Teknik Pengumpulan Data}

Demi menemukan data yang akurat, peneliti memerlukan teknik ini untuk memperoleh validitas data yang tinggi, sehingga mampu mengungkapkan permasalahan yang diteliti. 


\section{Observasi Terstruktur}

Bagian dari observasi terstruktur ialah observasi yang telah dipersiapkan dengan baik dan sistematis, yang nantinya apa saja yang akan diamati, kapan waktu penelitian dilaksanakan dan dimana tempat penelitiaan dilakukan. Peneliti melakukan observasi untuk mengetahui keadaan dan kondisi di Pesantren Terpadu Darussyifa AlFithroh Sukabumi, baik sarana prasarana, struktur organisasi, proses pembelajaran, keadaan guru dan murid yang terkait erat dengan penelitian yang dilakukan.

\section{Wawancara Tidak Terstruktur}

Peneliti melakukan wawacara tidak terstruktur kepada kyai dan guru, dimana peneliti melakukan penelitian dengan bebas dan tidak menggunakan pedoman yang sitematis tentang pedoman-pedoman wawancara yang lengkap untuk pengambilan datanya. Dan pedoman dilakukan dalam wawancaranya hanya menggunakan beberapa garis besar permasalahannya untuk dipertanyakan.

\section{Dokumentasi}

Dokumentasi adalah pengumpulan, penelitian, pengolahan, penyimpanan berupa informasi untuk menyempurnakan bidang pengetahuan, pemberitahuan atau pengumpulan dari bukti-bukti atau keterangan. Teknik ini dilakuakn untuk melakukan dokumentasi sebagai penghimpun data yang berkaitan dengan dokumen tentang guru, santri, proses pembelajaran, absensi guru, penilaian guru dan lain-lain yang nantinya dapat membantu atau mendukung penelitian ini.

\section{Kuesioner (Angket)}

Peneliti melakukan Teknik pengumpulan data dengan menggunakan teknik
Kuesioner. Yaitu dengan cara melakukan pengumpulan beberapa data dengan cara memberikan seperangkat pernyataan atau pertanyaan secara tertulis untuk diberikan kepada guru untuk dijawabnya. Teknik ini digunakan untuk mengetahui dan mengukur sejauh mana efektivitas kepemimpinan kharismatik kyai dalam meningkatkan kinerja guru di Pondok Pesantren Terpadu Darussyifa Al-Fithroh Sukabumi.

\section{Skala Likert}

Penelitian ini mengukur efektivitas kepemimpinan kharismatik kyaidalam meningkatkan kinerja guru. Skala likert dipergunakan untuk menguji dan mengukur bagian pembelajaran yang biasanya lebih efektif. Biasanya skala likert menggunakan beberapa variabel yang nantinya dapat diukur dan diperluas menjadi beberapa indikator variabel. Indikator-indikator tersebut dapat dijadikan sebagai acuan untuk menyusun instrumen yang berupa pernyataan-pernyataan atau pertanyaan.

\section{Teknik Analisis Data}

Analisis data dalampenelitian ini menggunakan model dari analisis data komparasi dengan cara membandingkan efektivitas kepemimpinan kharismatik kyai dalam meningkatkan kinerja guru di Pondok Pesantren Terpadu Darussyifa Al-Fithroh.

\section{HASIL DAN PEMBAHASAN}

\section{Hasil}

Didalam pondok pesantren kepemimpinan atau pemimpin dipegang penuh oleh seorang kyai, karena setiap pondok pesantren pasti ada kyai yang memimpin. Secara terminolgi kyai adalah pendidri atau pemimpin sebuah pondok pesantren. 
Diantara macam-macam kepemimpinan kyai adalah kepemimpinan kharismatik telah ditemukan di beberapa pondok pesantren. Kepemimpinan kharismatik tidak dapat dipelajari. Oleh karena itu ada beberapa aspek dari kepemimpinan kharismatik yang dapat digunakan oleh siapa saja. Karisma hadir dari ketekunan dan kegigihan dalam melakukan suatu kegiatan yang benar-benar digandrungi. Pemimpin kharismatik mencurahkan segenap emosinya dalam kegiatan seharihari. Hal ini menjadikan dia dampak energik, antusiastik dan menarik.

Kinerja guru merupakan kemampuan seorang guru dalam melaksanakan tugas pembelajaran di madrasah dan bertanggungjawab atas peserta didik di bawah bimbingannya. Oleh karena itu kinerja guru merupakan sebuah kondisi dimana seorang guru menunjukkan kemampuan dan perbuatannya selama melakukan aktivitas pebelajaran.

Adapun hubungan atau keterkaitan antara kepemimpinan kyai dalam kinerja guru ialah Kepemimpinan kharismatik kyai sangat berpengaruh terhadap kinerja guru karena kharismatik kyai dalam memimpin selalu memotivasi dan mendorong guru agar menjalankan tugas sebaik-baiknya tanpa memikirkan halangan dan rintangan.

Proses kepemimpinan kharismatik kyai merupakan proses interaktif dan dinamis dalam memengaruhi orang lain, dalam proses tersebut seorang pemimpin kharismatik harus memiliki kemampuan yang menginspirasi dan memotivasi bawahannya untuk mendapatkan hasil yang maksimal sesuai tujuan yang diinginkan tanpa menghiraukan rintangan dan pengorbanan. Efektivitas kepemimpinan kharismatik kyai setidaknya bisa terlihat dari tujuan dan prilaku pemimpin/ kyai tersebut, baik dalam merencanakan, mengorganisasikan, mendelegasikan tugas, dan memberikan motivasi kepada guru, sehingga guru dapat menjalankan kewajiban dan tanggung jawabnya dengan baik sesuai tujuan yang ingin dicapai.

Efektivitas kepemimpinan kharismatik Kyai dengan meningkatnya kinerja guru sangat berhubungan erat dan saling melengkapi satu sama lain sesuai tujuan dari pada kepemimpinan kharismatik dalam kinerja guru yaitu menciptakan guru-guru yang mampu meningkatkan kinerja dalam melaksanakan tugas. Sehingga di pondok pesantren dalam semua kegiatan akan berjalan lancar sesuai tujuan yang dinginkan.

Penyajian data pada penelitian ini diperoleh dari data responden dengan mengacu pada data hasil angket. Data responden adalah data yang diperoleh dari hasil penelitian di Pondok Pesantren Terpadu Darussyifa Al-Fithroh, sedangkan yang menjadi responden adalah guru-guru di Pondok Pesantren Terpadu Darussyifa AlFithroh tahun pelajaran 2016/2017 yang berjumlah 150 0rang. Manfaat digunakannya data responden untuk memenuhi kebutuhan peneliti dalam menentukan efektif atau tidaknya kepemimpinan kharismatik kyai dalam meningkatkan kinerja guru di Pondok Pesantren Terpadu Darussyifa Al-Fithroh dalam mengelola dan mengatur guru-guru.

Hasil data angket adalah skor mentah, sehingga dibutuhkan pengelolaan skor mentah menjadi skor perolehan. Seluruhangket yang diberikankepada guru terdiridari 12 soal yang meliputi 5 indikator dan aspek penilaian sesuai dengan pendapat para guru mengenai kepemimpinan kharismatik kyai atau pemimpinnya. Hal ini dimaksudkan untuk mengukur dan mengetahui sejauhmana efektivitas kepemimpinan kharismatik kyai dalam 
meningkatkan kinerja guru di Pondok Pesantren Terpadu Darussyifa Al-Fithroh yang dilaksanakan oleh pemimpin dalam mengatur dan menjalankan bawahannya. Apakah sudah efektif, kurang efektif atau tidak efektif, sesuai pendapat dan harapan guru-guru.

Berdasarkan indikator dari kepemimpinan kharismatik kyai dalam meningkatkan kinerja guru adalah:

a. Guru mentaati perintah kyai dengan kesadaran tinggi. Agar terciptanya kinerja guru yang baik yang harus dilakukan ialah guru mentaati sega perintah kyai dengan tingkat kesadaran yang tinggi, dengan itu akanterjadi keikhlasan dalam menjalankan program dengan baik.

b. Guru meyakini bahwa pendapat dan keyakinan kyai itu benar. Dalam sebuah lembaga pendidikan apabila guru ragu dengan keputusan dan keyakinan kyai, maka tidak akan terjadi keselarasan sehingga guru tidak akan maksimal karena apa yang dilakukan tidak selaras dengan keinginan seorng kyai.

c. Guru termotivasi dengan wibawa seorang kyai. Dalam melaksanaan tugasnya guru akan melihat dan mencontoh kyainya, diantaranya adalah wibawa kyai yang dapat berpengaruh kepada guru yang menjalankan tugas.

d. Guru memiliki hubungan dan kerjasama yang baik dengan kyai. Apabila dalam sebuah lembaga pendidikan ingin memperoleh hasil yang maksimal, harus ada kekompakan antara kyai dan guru. Diantara kekompakan tersebut adalah adanya hubungan dan kerjasama yang baik antara guru dan kyai.

a. Guru mendapatkan reward (pengahargaan dari kyai). Reward sangat perludiberikan oleh seorang kyai, karena akan mempengaruhi motivasi guru dalam melaksanakan kewajibannya. Dengan adanya reward guru akan semakin semangat dalam menjalankan tugas sehingga kinerjanya semakin meningkat.

Dalam pengolahan data ini, peneliti menggunakan rumusan kai kuadrat dengan maksud untuk menguji dan membandingkan efektivitas kepemimpinan kyai dalam meningkatkan kinerja guru di Pondok Pesantren Terpadu Darussyifa AlFithroh (lihat tabel 1).

Tabel 1 Efektivitas kepemimpinan kharismatik kyai terhadap kinerja guru

\begin{tabular}{|c|c|c|c|c|c|}
\hline No. & Penilaian & Efektif & $\begin{array}{l}\text { Kurang } \\
\text { Efektif }\end{array}$ & $\begin{array}{l}\text { Tidak } \\
\text { Efektif }\end{array}$ & Total \\
\hline 1 & $\begin{array}{l}\text { Guru mentaati perintah kyai dengan } \\
\text { kesadaran tinggi }\end{array}$ & 194 & 14 & 1 & 210 \\
\hline 2 & $\begin{array}{l}\text { Guru meyakini bahwa pendapat dan } \\
\text { keyainan kyai itu benar }\end{array}$ & 251 & 60 & 4 & 315 \\
\hline 3 & Guru termotivasi wibawa seorang kyai & 127 & 71 & 12 & 210 \\
\hline 4 & $\begin{array}{l}\text { Guru memiliki hubungan dan komunikasi } \\
\text { yang baik dengan kyai }\end{array}$ & 224 & 80 & 11 & 315 \\
\hline 5 & $\begin{array}{l}\text { Guru mendapatkan reward (penghargaan) } \\
\text { dari kyai }\end{array}$ & 105 & 96 & 9 & 210 \\
\hline Total & & 901 & 322 & 37 & 1260 \\
\hline
\end{tabular}

Sumber : Hasil perhitungan yang didapat dari hasil angket. 
Rumus yang digunakan adalah:

Rumus Kai Kuadrat

$$
X^{2}=\sum \frac{(f o-f e)^{2}}{f e}
$$

Mencari (fe)

$$
\mathrm{fe}=\frac{(\Sigma \mathrm{fk}) \cdot(\Sigma \mathrm{fb})}{\Sigma T}
$$

$$
\begin{aligned}
& \mathrm{dk}=(\mathrm{k}-1) \cdot(\mathrm{b}-1) \\
& \mathrm{dk}=(3-1) \cdot(5-1) \\
& \mathrm{dk}=2 \times 4=8
\end{aligned}
$$

Hasil dari perhitungan diatas menunjukkan bahwa harga $\mathrm{x}^{2} \mathrm{o}$ adalah 448,6096. Maka, berdasarkan tabel kai kuadrat pada taraf signifikansi $5 \%$ dengan $\mathrm{dk}=8$, menghasilkan kesimpulan seperti pada tabel 2 .

Tabel 2 Taraf signifikasi dan kesimpulan

\begin{tabular}{lll}
\hline Harga $x^{2} 0$ & $\begin{array}{l}\text { Taraf } \\
\text { Signifikasi }\end{array}$ & Kesimpulan \\
\cline { 2 - 2 } & $5 \%$ & \\
\cline { 2 - 2 } 119,3925 & 15,507 & $19,3925>15,507$ \\
\hline
\end{tabular}

Hasil perhitungan diperoleh harga $\mathrm{x}^{2} \mathrm{o}=$ 119,3925, dengan memperhitungkan terlebih dahulu degress of freedom(df) atau derajat kebebasannya (dk) seperti yang terdapat pada tabel . pada tabel tersebut memiliki kolom (k) 3 buah (jadi $\mathrm{k}=3$ ) dengan baris 5 buah (jadi $b=5$ ).

Dengan demikian, dk yag dicari disini adalah sama dengan hasil perkalian antara banyaknya kolom dikurangi 1 , yaitu (k-1) dan banyaknya lajur yang terdapat pada tabel perhitungan yang dikurangi 1, yaitu $(\mathrm{b}-1)$, atau singkatnya $\mathrm{dk}=(\mathrm{k}-1)(\mathrm{b}-1)$ atau $(3-1)(5-1)=8$.

Pengurangan 1 dari jumlah kolom dan jumlah baris yang terdapat pada tabel itu adalah disebabkan adanya kebebasan yang terbatas dalam mengisi angka pada bari terakhir sesudah kolom atau baris yang lain terisi. Jadi sesudah (k-1) atau (b-1) terisi, tidak ada lagi kebebasan unutk kolom atau baris terakhir, karena jumlah menurut baris itu telah tertentu. Dengan $\mathrm{dk}=8$, maka diperoleh harga kritik kai kuadrat pada tabel nilai kai kuadrat dengan taraf signifikasi 5\% adalah 15,507. Perbandingan harga kritik $\left(\mathrm{x}^{2} \mathrm{o}=119,3925\right)$ terhadap (taraf signifikasi $5 \%=15,507$ ) adalah lebih besar (119,3925>15,507).

Dari hasil perbandingan tersebut, dapat disimpulkan bahwa hipotesis nilai (Ho) yang menyatakan kepemimpinan kharismatik kyai dalam meningkatkan kinerja guru tidak efektif "ditolak", karena terdapat perbedaan yang diobservasi dengan frekuensi teoritik. Dengan demikian, hipotesis alternatif ( $\mathrm{Ha}$ ) yang menyatakan bahwa kepemimpinan kharismatik kyai dalam meningkatkan kinerja grur efektif "diterima".

Berdasarkan hasil angket yang telah dikorelasikan dengan indikator kepemimpinan kharismatik kyai dalam meningkatkan kinerja guru seperti pada Tabel 3.

Dari tabel 3, dapat disimpulkan bahwa kepemimpinan kharismatik kyai yang efektif (lebih diminati dan disukai oleh para guru) adalah kepemimpinan kharismatik Kyai yaitu yang memiliki indikator Guru meyakini bahwa pendapat dan keyainan kyai itu benar, sedangkan kepemimpinan kharismatik yang kurang efektif adalah kepemimpinan yang selalu memberikan reward kepada guru. Hal ini dikarenakan dalam kepemimpinan kyai di Pondok Pesantren Terpadu Darussyifa Al-Fithroh Perguruan Yaspida Sukabumi lebih terlihat memiliki ciri dan sifat kepemimpinan 
kharismatik. Seperti halnya pimpinan dan menerima masukan dan kritikan yang pondok pesantren yang lebih membangun demi kemajuan pondok mengutamakan kesejahteraan bawahannya pesantren.

Tabel 3 Kepemimpinan karismatik kyai yang Efektif sehingga kinerja guru lebih meningkat

\begin{tabular}{llrrr}
\hline No. & \multicolumn{1}{c}{ Penilaian } & Efektif & $\begin{array}{r}\text { Kurang } \\
\text { Efektif }\end{array}$ & $\begin{array}{c}\text { Tidak } \\
\text { Efektif }\end{array}$ \\
\hline 1 & Guru mentaati perintah kyai dengan kesadaran tinggi & 194 & 14 & 1 \\
2 & $\begin{array}{l}\text { Guru meyakini bahwa pendapat dan keyainan kyai itu } \\
\text { benar }\end{array}$ & 251 & 60 & 4 \\
$3 \quad$ & Guru termotivasi dengan sikap dan prilaku kyai & 127 & 71 & 12 \\
4 & $\begin{array}{l}\text { Guru memiliki hubungan/komunikasi yang baik dengan } \\
\text { kyai }\end{array}$ & 224 & 80 & 11 \\
5 & $\quad$ Guru mendapatkan reward (penghargaan) dari kyai & 105 & 96 & 9 \\
Total & 901 & 322 & 37 \\
\hline
\end{tabular}

Penelitian yang dilaksanakan di Pondok Pesantren Terpadu Darussyifa Al-Fithroh Perguruan YASPIDA Desa Cipetir Kecamatan Kadudampit, Kabupaten Sukabumi menunjukkan bahwa kepemimpinan kharismatik kyai dalam meningkatkan kinerja guru efektif, hal ini terbukti dari hasil uji hipotesis $x^{2} 0$ sebesar 119,3925. Angka korelasi ini lebih besar dibandingkan dengan $\mathrm{x}^{2} \mathrm{t}$ pada taraf signifikasi $5 \%=$ 15,507 . Hasil uji hipotesis ini memberikan makna bahwa terdapat keefektifan kepemimpinan kharismatik kyai dalam meningkatkan kinerga guru di Pondok Pesantren Terpadu Darussyifa Al-Fithroh.

Efektivitas kepemimpinan kharismatik Kyai dalam meningkatkan kinerja guru, dapat dinilai dari kemahiran seorang pemimpin dalam mengatur bawahnnya dan ketepatan model kepemimpinan yang digunakan pemimpin dan menghasilkan kinerja guru yang baik. Hal tersebut dapat dilihat dari sebgaian besar guru dapat melaksanakan tugas dan tanggung jawabnya dengan baik sesuai prosedur dantujuan yang diinginkan.
Adapun pembuktian guru dapat menerima dan memahami serta melaksanakan perintah dan tugas dari pimpinan dapat dilihat dari hasil angket, sedangkan kinerja guru dapat dilihat dari daftar hadir guru, dan penilaian guru dalam menjalankan tugas dan tanggungjawabnya yang telah dinilai oleh pimpinan Pondok Pesantren Terpadu Darussyifa Al-Fithroh.

Selain itu, faktor pendukung terkait dengan efektivitas kepemimpinan kyai dalam meningkatkan kinerja guru di Pondok Pesantren Terpadu Darussyifa Al-Fithroh Perguruan YASPIDA Sukabumi dapat dinilai dari beberapa faktor berikut.

a. Kehadiran guru Pondok Pesantren yang hamper selalu berada di tempat, sesuai dengan jadwal yang ditentukan. Dengan selalu adanya guru dalam mengajar, murid dapat belajar lebih giat dan termotivasi untuk belajar dengan baik.

b. Kehadiran guru yang berbentuk militansi terhadap pondok pesantren, bukan hanya mengajar di kelas, tetapi dilibatkan dalam bimbingan terhadap 
murid dan pengabdian untuk pondok, baik dari tenaga, pikiran, dan lain-lain.

\section{Pembahasan}

Kepemimpinan merupakan sifat dari pemimpin dalam melaksanakan tugas dan kewajibannya serta tanggung jawabnya seacara moral dan legal formal atas seluruh pelaksaan wewenangnya yang telah didelegasikan kepada orang-orang yang dipimpinnya. Kepemimpinan banyak di definisikan dalam Al-Qur'an seperti Firman Allah SWT. Yang artinya: Allah telah berfirman bahwa Allah telah menjadikan mereka itu sebagai pemimpin-pemimpin yang memberi petunjuk dengan perintah Kami dan telah Kami wahyukan kepada, mereka mengerjakan kebajikan, mendirikan sembahyang, menunaikan zakat, dan hanya kepada kamilah mereka selalu menyembah. (QS. Al-Anbiya [21] 73).

U Saefullah (2014) dalam bukunya menyatakan bahwa Kepemimpinan merupakan seni dan keterampilan yang dimiliki seorang pemimpin dalam memanfaatkan kekuasaannya untuk memengaruhi bawahannya agar melaksanakan tugas dan tanggung jawabnya yang mengarah pada tujuan yang telah ditetapkan. Kepemimpinan di Pondok Pesantren Terpadu Darussyifa Al-Fithroh di pegang oleh seorang kyai bernama Dr. KH. E. Supriatna Mubarok, MSc, MM. Kepemimpinan yang dilakukan adalah memipin para guru sebagai pendukung dalam perjalanan pondok pesantren, terutama dalam proses pembelajaran terhadap murid.

Gaya kepemimpinan kyai di pondok pesantren darusyifa al-fithroh, memang sulit ditebak. Entah gaya kepemimpinan apa yang digunakan untuk memimpin para guru, karena kepemimpinannya terlihat melengkapi semua agay kepemimpinan yang ada seperti gaya otoriter, gaya demokratis, gaya pseudo demokratis, gaya karismatik dan gaya laissez-faire.

1. Gaya Otoriter

Gaya otoriter adalah kepemimpinan yang bersifat diktator. Pemimpin yang otoriter tidak menghendaki musyawarah, kepemimpinan baginya berarti mengerakan dan memaksa.

2. Gaya Demokratis

Gaya demokratis adalah lawan dari otoriter, kepemipinan demokratis menjadikan bawahan atau anggota sebagai patner. Pemimpin demokratis selalu berusaha mendengar saran dan pendapat bawahan.

3. Gaya Pseudo Demokratis

Gaya kepemimpinan ini nampak dari luar seperti demokratis, tetapi hakikatnya otoriter. Pemimpin melakukan musyawarah untuk menentukan kebijakan atau keputusan dengan cara pemaksaan.

4. Gaya karismatik

Kepemimpina karismatik memiliki kemampuan menginspirasi dan memotivasi pengikutnya untuk melakukan sesuatu yang lebih tanpa menghiraukan rintangan dan pengorbanan

5. Gaya Laissez-Faire

Gaya kepemimpinan yang memberikan keleluasaan bertindak sekehendak anggota.Pembagian tugas dierahkan sepenuhnya kepada bawahan tanpa petunjuk atau arahan.

Dari semua gaya kepemimpinan tersebut hampir seluruh ada dalam diri kyai Pondok Pesantren Terpadu Darussyifa Al-Fithroh, karena terlihat dari proses kepemimpinannya terhadap para guru. Diantara banyaknya gaya kepemimpinan, 
gaya kepemimpinan kyai di Pondok Pesantren Tepadu Darussyifa Al-Fithroh setelah diteliti kepemimpinan kyai tersebut lebih mengarah dan terlihat seperti kepemimpinan kharismatik. Saefullah falah (2016) berpendapat bahwa dalam teori kepemimpinan, kepemimpinan kharismatik secara bahasa ialah Charisma yang memiliki arti pemberian yang diilhami secara illahi (divinely inspired gift). Seperti kemampuan membuat mukjizat atau meramal masa depan. Kepemimpinan kahrismatik dapat diketahui dalam bentuk pengaruh yang bukan berasal dari kebiasaan atau kekuasaan formal, tetapi dari persepsi pengikut bahwa pemimpin tersebut diberkahi kualitas lua biasa.

Kepemimpinan kharismatik kyai tersebut dapat diketahui dari karakter, sikap dan tingkah laku kyai dalam memimpin para guru dalam mengelola pondok. Guru- guru di Pondok pesantren menyatakan bahwa kepemimpinan kyainya sangat unik. Karena secara tidak langsung guru merasa sangat cepat dipengaruhi oleh kyainya, baik dalam memerintah maupun memberikan motivasi kerja. Dengan melihat ciri-ciri kepemimpinan kyai tersebut dan dmengacu pada hasil wawancara dengan para guru peneliti menyimpulkan bahwa kepemimpina kyai di pondok pesantren terpadu darussyifa al-fithroh memiliki gaya kepemimpinan kharismatik.

Kepemimpinan seorang kyai tidak akan berhasil apabila tidak ada yang mendukung. Di pondok pesantren terpadu darussyifa alfithroh yang mendukung seorang pemimpin yaitu guru sebagai bawahan dari kyai. Guru akan menjadi salah satu faktor penunjang keberhasilan pondok pesantren, manakala guru mampu menjalankan tugas dan tanggung jawabnya semaksimal mungkin. Dengan cara melaksanakan tugas dan tanggung jawabnya sebaik-baiknya. Kinerja guru akan menjadi patokan berhasil tidaknya seorang pemipin dalam memimpin.

Supardi (2013) menyatakan bahwa kinerja seorang guru dalam pelaksanaan proses pembelajaran di madrasah dan bertanggungjawab atas peserta didik dibawah bimbingannya dengan menghasilkan peserta didik yang berprestasi baik dalam bidang akademik maupun non akademik. Apabila guru mampu menghasilkan peserta didik yang berprestasi, maka guru tersebut telah memiliki peningkatan dalam kinerja. Kinerja guru tidak terwujud dengan begitu saja, tetapi kinerja guru di pengaruhi oleh faktorfaktor tertentu, baik faktor internal maupun eksternal.

Faktor internal kinerja guru timbul dari dalam guru tersebut, seperti halnya faktor keterampilan, kepribadian, persepsi, dan motivasi menjadi guru. sedangkan faktor eksternal kinerja guru timbul dari luar guru, seperti faktor gaji, sarana prasarana, lingkungan kerja dan kepemimpinan. Kinerja guru yang baik bukan hanya akan mendapatkan pengahargaan dari pimpinan, akan tetapi akan mendapatkan penghargaan dari Allah SWT, sebagaiamana Firman Allah SWT. Yang artinya : Wahai orang-orang yang beriman. Allah telah memerintahkan kamu untuk berlapang-lapang dalam majlis. Maka kamu haru berlapang-lapang dalam majlis, sehingga Allah akan memberikan kelapang bagimu. Dan Allah telah memerintahkan kamu untuk berdiri dalam majlis , maka kamu harus berdiri dalam majlis, sehingga Allah akan mengangkat orang-orang yang beriman dan Allah akan memberi ilmu pengetahuan beberapa derajat. Karena Allah megetahui segala aktivitas yang kamu kerjakan. (QS. AlMujadalah [28] : 11). 
Agar guru dalam melaksnakan tugas menghasilkan kinerja yang baik, maka kinerja gutu tidak akan terlepas dari faktorfaktor yang mempengaruhi kinerja guru yaitu yang pertama faktor individual seperti halnya pengetahuan, keterampilan, kemampuan, motivasi, kepercayaan, nilainilai dan sikap. Faktor yang kedua adalah faktor organisasional seperti sumberdaya, kepemimpinan, imbalan dan struktur dan yang ketiga ialah faktor psikologis yaitu persepsi, sikap, kepribadian, belajar dan motivasi. Guru-guru di Pondok Pesantren Terpadu darussyifa al-fithroh merupakan guru yang memilki kinerja yang baik dan meningkat. Tentu saja peningkatan kinerja tersebut tidak terlepas dari kepemimpinan seorang kyai yang dapat mengatur dan memotivasi dalam menjalankanj tugas dan tanggung jawabnya.

Dalam mengefektifkan kepemimpinan kharismatik kyai, kyai mengimplementasikan kepemimpinannya kepada guru-guru dengan cara melakukan pembianaan kepada guru-guru secar rutin setiap minggunya. Bukan hanya pembinaan dari segi motivasi, tetapi kyai melakukan pengajian secara rutin khusus untuk para guru-guru sebagai ilmu tambahan dan pedoman dalam menjalankan proses pembelajaran. Hal tersebut dilakukan agar guru termotivasi dalam menjalankan tugas dan tanggung jawabnya, sehingga akan tercipta kinerja yang baik serta kinerja guru akan lebih meningkat. Pengefektifan kepemimpinan tersebut tidak terlepas dari beberapa indikator kepemimpinan khrismatik yang menjadi pedoman atau petunjuk pelaksaan kepemimpinan khrismatik kyai dalam meningkatkan kinerja guru, sehingga lebih terarah dan tidak keluar dari tujuan yang telah ditetapkan. Indikator-indikator kepemimpinan kharismatik kyai tersebut sebagai berikut.

Indikator pertama mengenai guru mentaati perintah kyai dengan kesadaran tinggi. Agar terciptanya kinerja guru yang baik yang harus dilakukan ialah guru mentaati segala perintah kyai dengan tingkat kesadaran yang tinggi, dengan itu akan terjadi keikhlasan dalam menjalankan tugas dan tanggung jawabnya. Seperti halnya di Pondok Pesantren Terpadu Darussifa Al-Fithroh, setiap perintah kyai langsung dikerjakan dengan segera, tanpa menunda-nunda waktu.

Indikator kedua mengenai guru meyakini bahwa pendapat dan keyakinan kyai itu benar. Setiap guru di Pondok Pesantren Terpadu Darussyifa Al-Fithroh meyakini pendapat dan ketetapan kya itu benar, sehingga apa yang ditetapkan kyai, guruguru menerima dan menjalankan ketetapan tersebut tanpa ada pertanyaan atau protes, sekalipun kadangkala tidak sesuai dengan apa yang diingankan guru.

Indikator ketiga mengenai guru termotivasi dengan wibawa seorang kyai. Dalam melaksanaan tugasnya guru akan melihat dan mencontoh kyainya, diantaranya adalah wibawa kyai yang akan mempengaruhi kinerja guru. Di Pondok Pesantren Terpadu Darussyifa Al-Fithroh guru-guru dapat termotivasi dengan wibawa kyai, baik dalam bentuk perkataan maupun perbuatan.

Indikator keemat engenai guru memiliki hubungan dan komunikasi yang baik dengan kyai. Kyai dan guru di Pondok Pesantren Terpadu Darussyifa Al-Fithroh dapt dikatakan sebagai sebuah tim yang kompak, karena jarang terjadi permasalah diantara keduanya, semua itu tercipta karena hubungan dan komunikasi dapat terjaga dengan baik. 
Indikator yang terkahir mengenai guru mendapatkan reward (pengahargaan dari kyai). Di Pondok Pesantren Terpadu Darussyifa Al-Fithroh apabila guru berprestasi akan mendapatkan reward, seperti apabila guru berprestasi akan mendapatkan inventaris kendaraan operasional, adanya kenaikan gaji, fasilitas jasa asuransi serta ada kenaikan jabatan.

Meningkatnya kinerja guru akan diketahui setelah kyai melakukan penilaian terhadap kinerja yang telah dilaksanakan.

Priansa (2014) menyatakan bahwa penilaian kinerja guru ialah suatu sistem formal dan terstruktur yang digunakan untuk mengukur, menilai dan memetakan sifat-sifat yang berhubungan dengan pekerjaan, prilaku dan hasil kerja guru terkait dengan peran yang diembannya. Dengan demikian, penilaian kinerja guru merupakan hasil kerja guru dalam lingkup tanggung jawabnya.

Dalam penilaian kinerja guru tersebut ada beberapa aspek yang menjadi pedoman kyai dalam melakukan penilain kinerja guru, yaitu kemampuan menyusun rencana pembelajaran, melaksanakan pembelajaran, mengadakan hubungan antar pribadi, penilaian hasil belajar, pengayaan dan remidial. Selain itu kehadiran dan kepedulian guru terhadap sesuatau yang terjadi di lembaga pendidikan tempat guru tersebut mengajar juga dapat menjadi pedoman penilaian kinerja guru.

Dengan melakukan penilaian kinerja terhadap guru, dapat diketahui apakah kepemimpinan kharismatik kyai efektif dalam proses peningkatan kinerja guru. Setelah dilakukan penelitian kepemimpinan kharismatik kyai dalam meningkatkan kineja guru ialah efektif. Dengan capaian persantase $70 \%$. Persentase tersebut diketahui melalui proses penelitin yang dilakukan peneliti di Pondok Pesantren
Terpdu Daussyifa Al-Fithroh dengan mnenggunakan berbagai macam metode penelitian.

\section{KESIMPULAN DAN IMPLIKASI}

\section{Kesimpulan}

Penelitian ini mengkaji masalah efektivitas Kepemimpinan Kyai dalam meningkatkan kinerja guru di Pondok Pesantren Terpadu Darussyifa Al-Fithroh perguruan Yaspida Sukabumi. Indikator dari Kepemimpinan kharismatik tersebut yaitu indikator Guru meyakini bahwa pendapat dan keyainan kyai itu benar. Berdasarkan hasil perhitungan kai kuadrat pada pengujian hipotesis diperoleh $\mathrm{X}^{2}{ }_{\mathrm{o}}=119,3925$. Hasil ini kemudian dikonsultasikan pada nilai kritik taraf signifikan $\mathrm{X}_{\mathrm{t}} \mathrm{5} \%=15,507$ dengan $\mathrm{dk}=$ 8 dan ini berarti $\mathrm{X}^{2}{ }_{\mathrm{o}}$ observasi lebih besar dari $\mathrm{X}^{2} \mathrm{t}$ pada taraf signifikan $5 \%$. Persentase Kepemimpinan Kharismatik Kyai Dalam Meningkatkan Kinerja Guru 70 \% Efektif. Dengan demikian, hipotesis nihil Hoyang menyatakan kepemimpinan kharismatik kyai dalam meningkatkan kinerja guru tidak efektif "ditolak". Sedangkan hipotesis alternatif Hayang menyatakan bahwa kepemimpinan kharisamtik kyai dalam meningkatkan kinerja guru efektif "diterima".

\section{Implikasi}

Dalam perjalanan pondok pesantren kyai sangat berperan dengan dukungan guruguru sebagai tenaga pengajar, guna mencapai tujuan yang diingikan. Agar pesantren dapat berjalan dengan mulus, perlu adanya kekompakan antara kyai dan guru, diantaranya kepemimpinan yang dimiliki seorang kyai sehingga mampu menagtur dan memotivasi guru-guru dalam melaksanakan tugas dan tanggung 
jawabnya. Halnya kyai di Pondok Pesantren Terpadu Darussyifa Al-Fithroh dari sekian banyaknya tipe kepemimpinan, kyai lebih terlihat memiliki tipe kepemimpinan kharismatik yang dapat diterima guru-guru seingga berdampak pada kinerja guru menjadi lebih meningkat.

Adanya penelitian ini diharapkan menjadi sebuah masukan positif bagi lembaga atau Pondok Pesantren dalam implementasi kepemimpinan karismatik kyai dalam meningkatkan kinerja guru. Sehingga dapat menjadi pedoman pondok pesantren dalam proses perjalanan pondok pesantren kedepannya.

\section{DAFTAR PUSTAKA}

Falah, S. (2016). Pesantren, Kyai dan Masa Depan. Bogor: Santrinulis Publishing.

Priansa, D. J. (2014). Kinerja dan Profesionalisme Guru. Bandung: Alfabeta. Saefullah, U. (2014). Manajemen Pendidikan Islam. Bandung: Pustaka Setia.

Sugiyono. (2006). Metode penelitian kuantitatif, kualitatif, dan R\&D. AlfaBeta, Bandung.

Supardi. (2013). Kinerja Guru. Jakarta: Raja Grafindo Persada. 